\title{
ARTICLES
}

\section{BETWEEN MISSION AND COMMERCIALITY. PROFESSIONAL JOURNALISTIC STANDARDS IN THE MODERN MASS MEDIA MARKET}

\author{
by Iwona Hofman
}

The term State appropriately reflects the dichotomous condition of contemporary journalism. The tension between the commercial and the functional side of the mass media leaves the journalist standing alone on the battlefield facing a harsh dilemma to remain faithful to professional ethics or to give way to the pressure of ratings. In other words, striving to describe objectively, inform critically, and earnestly, leaves some space for your opponents or makes you dig out seemingly meaningful information and present it in the form of a factoid or a story that probably will not bring you closer to the truth but generates more buzz around the news and entertain the audience. It all comes down to a single choice - serious journalism versus tabloid journalism. In my opinion, it is a serious issue which has to be brought up in any discussion concerning the media. One can see it more clearly by looking closely at both notions. Serious journalism is responsible for its words, along with the awareness of the influence it has on the audience. Tabloid journalism, on the other hand, is marked by a nonchalant audience attitude. It is aware of its influence on the fans, but its impact is simplified compared to mass media doctrines, and comes down to the brutal slogan "riffraff would buy". Though, not making a big fuss, it is worth saying that with journalism, having the meaning of a pub- 
lic service and letting down society, we are dealing with conflict of values and hitting rock bottom.

Mass media, the doctrine of social responsibility not only differentiates public from commercial media, but also assigns the first with certain missionary functions, e.g. informing, educating and creating cultural functions. These roles can be fulfilled by the media under conditions of independence in such areas as politics, economics and social life. This enables media to accomplish any task consequent upon a doctrine, under multiple conditions, with the most important two being freedom of speech and the stabilization of financing the public media sector. ${ }^{1}$

Polish "Press policy" (art. 10, Act. 1) points out that it is the journalists' responsibility to keep the society and the State informed. Calling the media "the fourth estate" hides a priori statement, that the fulfillment of information function can, and actually should rely on the critical evaluation of State activity spheres, e.g. gaining power and State administration. This plank leads the media to having the position of a watchdog. ${ }^{2}$ An institutional guarantor of assignment completion are Polish journalism organizations like the Polish Journalists' Association, the Republic of Poland Journalists' Association, the Catholic Journalists Association, and the Local Press Association, which are natural spheres for the integration of journalists' efforts to uphold the social status of the profession. Formal

1 Compare: J. Adamowski, Media w państwie wspótczesnym, Warszawa 2001, B. Dobek-Ostrowska (ed.), Transformacja systemów medialnych w krajach Europy ŚrodkowoWschodniej po 1989 roku, Wrocław 2002, idem, Media masowe w systemach demokratycznych. Teoretyczne problemy i praktyczny wymiar komunikowania politycznego, Wrocław 2003, T. Goban-Klas Media i komunikowanie masowe. Teorie i analizy prasy, radia, telewizji i Internetu, Warszawa-Kraków 2002, T. Płonkowski, Amerykańska koncepcja społecznej odpowiedzialności dziennikarzy, Warszawa 1995; K.T. Teoplitz, Dokąd prowadza nas media, Warszawa 2006.

2 Compare: J. Sobczak, Ustawa prawo prasowe. Komentarz, Warszawa 1999, E. Nowińska, Media jako czwarta władza, [in:] Media, władza, państwo, ed. M. Magoska, Kraków 2005, R. Bartoszcze, O wolności wypowiedzi, [in:] W. Nentaing, Czwarta władza? Polskie media wpływaja na opinię publiczna, Poznań 1995; K. Kowalska, Czwarty stan - dziennikarz wobec wyzwań wspótczesnej sfery publicznej, [in:] Dziennikarstwo, media, społeczeństwo, ed. S. Mocek, Warszawa 2005, pp. 63-84. It is worth asking: whom the term "the fourth estate" refers to? To journalists, editors, media owners?, ibidem, W. Bereś, Czwarta władza. Najważniejsze wydarzenia medialne III RP, Warszawa 2000. 
benchmarks can serve such documents as the Declaration of the Rules of the International Journalists' Federation, the Media Ethics Card, the Journalist's Ethics Code, the Journalistic Code on Customs, and the related pragmatic rules of the Media Ethics Code, in particular. In practice they are commonly infracted by, among other things, bias, media engagement in politics and verbal aggression.

Talking about the socially-useful roles of the media, it is worth highlighting, in the missionary context, that the presentation of ideas and opinions "make their functioning more real" in the public debate. ${ }^{3}$ Reversing the order by opting out of serious journalism, the media excluded themselves from the public debate. ${ }^{4}$

Another observation concerns the evolution of the "professionalism" concept, which today seems to be just a safe niche for a journalist who is tired of ongoing news and the team order to seize topicality. Philip Eliot notices that "any attempts at professional journalist are based on such standard competitions such as fact coherence, meeting deadlines, style of presentation and news evaluation." 5 These basic journalism markers became positive distinguishing features on the miserable background of communications. I reckon that as they are in the strict dependence, the work ethic is jeopardized by the professionalism's losing the sense of the phenomenon. When analyzing the causes of this state of affairs, it would

3 According to Louis Althusser's theory, compare: L. Taylor, A. Willis Medioznawstwo. Teksty, insytucje i odbiorcy, Kraków 2005, pp. 32-34.

4 Edwin Bendyk has presented this issue in a very interesting way, namely by asking a question: is the media still a part of an independent public sphere or one of the elements of show-business offer? The journalist pointed out, important, in his opinion, circumstances of consideration of this issue: atrophy of the public sphere as a result of the media commercialization, society fragmentation (it is becoming more and more difficult to create a coherent announcement), IT technology development dethroning the press as information provider, compare: E. Bendyk, Dziennikarz w postmodernistycznym świecie mediów, [in:] Dziennikarstwo..., pp. 89-91.

5 P. Elliot, Media organizations and occupations, [in:] Mass Communications and Society, ed. J. Curran, London 1977, ibidem, 131. Henceforth this issue is described in a more caustic manner: "the professionalism in professions related to the media is a way of adapting to the role conflicts dilemmas where proficiency and competence in routine tasks preparation are brought to a level of professional ideal". 
be worth putting this problem into a broader context of changes which occurred in the media market after 1989, and the establishment of a democratic model. Expectations raised by excluding media from politics in Eastern and Central Europe proved to be unrealistic in the short term. This happened because there were "wheels within wheels". Media divided itself into two groups, as Noam Chomsky stated. "The first one is to entertain the crowd - sport, tournaments, gossips and scandals. The second

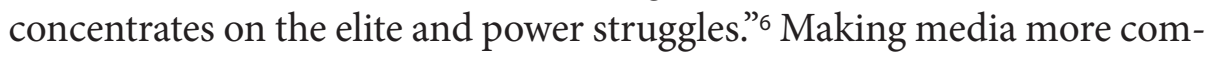
mercial and political (in contrast to making politics more media-oriented) plays a deciding role in shaping the current view of mass opinion. The positive outcomes of changes in media system in Europe are: enrichment of the range of titles, media segmentation, easy information access, and no censorship or cover stories. The negative aspects of the media are: the outcomes of the struggle for advisers and incomes, international media syndicate monopoly "standardizing" its own independent media into social and cultural contexts and consumer-culture domination. Among other things, a negative outcome would be lowering the prestige of the journalist's occupation, with an impact on media credibility, spreading the freelance journalist model, entertainment primacy and tabloidization. On the other hand, maybe we should take into account the dynamic nature of the new media - like Klaus Bachmann, German press correspondent in Poland of many years - and consider the way of achieving agreement between value and time criteria. Bachmann wrote: "Media are simplifying, campaigning, organizing readers, personalizing, moralizing and emotionalizing. They have to do it if they are to explain the world to the reader in 30 minutes." 7

In the critical evaluation of media conditions, the leaders are - what is even more characteristic - the journalists themselves. Jacek Żakowski makes it clear that, what interests him are not the entertaining media (they are useless or even destructive in democracy), but the opinion-makers. He wrote: "this regress can be measured in many ways. Shortening the

6 Compare: A. Szostkiewicz, Wioska gapiów, Niezbędnik inteligenta, „Polityka” 2004, No. 27 (2459), p. 20.

7 K. Bachmann, Pożytki ze wścibskiej prasy, „Gazeta Wyborcza” 2008, No.138. 5748, p.27. 
texts every time makes the subject presentation limited. The rising contribution of so called soft information (...), i.e. lowering of content level, can be seen in the more readable simplification by lobbyists and PR practitioners manipulating the media. There is an increasing role of emotional transfers or simple unreliability which everyone, the media writes or talks about, is experiencing. It pushes media into a frivolous syndrome. They are no longer a serious source of information and thoughts." ${ }^{3}$ The journalistic writer not only points out serious displays of journalistic regression, but also signifies the long-lasting consequences of the asymmetry between the well-informed media and the recipient, who is receiving only carefully selected information.

The above observations are strictly connected with the media studies of influence concepts interpretation, i.e. the cultivated and growing cognisance gap conception. The first states that reality distortion makes the recipient more interested and involved with a negative outcome of taking the distorted reality as factual. ${ }^{9}$ This is where the discouraging level of emotions and sensation in media comes from. I do agree with the British writer and journalist, Michael Ignatieff, who states that "real commerce is not the one that shows commercials or infantile entertaining programmes" but re-states the information itself. By the marketing rule "we are faster, we have the highest ratings, our correspondent got to the place, where no other television crew had been before - you have to believe us, we know better, what is more important."10

Adam Szostkiewicz has found perfect definitions for describing criteria of media effectiveness and their application time, market results, inner quality control. It seems that the second link, market results, is the crucial one. ${ }^{11}$ Paraphrasing Żakowski's words - the only mission for media owners is high profitability.

8 J. Żakowski, Mea culpa, „Polityka” No. 20 (2654), p. 17.

9 It is worth mentioning the constructive directions of Walery Pisarek and Stanisław Michalczyk concerning content analysis method to measure the media essence. Compare: W. Pisarek, Wstęp do nauki o komunikowaniu, Warszawa 2008; S. Michalczyk, Społeczeństwo medialne, Katowice 2008.

10 A. Szostkiewicz, Wioska..., p. 21.

11 Ibidem, pp.20-21. 
I will ask colloquially, does the industry know, or not? Of course it does. However, struggling for the audience, not having an integrated plan in the form of properly-functioning organizations, fighting off attacks from politicians, who treat the media like a bonus granted for winning elections, make the media not strong enough to articulate disagreement on the profession's pauperisation.

The above mentioned article of Jacek Żakowski prompted interesting polemics from Maciej Wierzyński. His experiences as the head of Radio Free Europe and the Polish section of the Voice of America in Washington, currently the director of strategy in TVN 24 channel, gives him rational, and even optimistic insight. He assumes that commercialization, tabloidization, media politicization and no demand for serious journalism theses as proved. Wierzyński claims that they are mainly media diseases of childrens' age taking place in democratic Poland. He expects them to take a natural turn into "high-standard newspapers" and improvement in journalists training quality. ${ }^{12}$

I can only agree with this postulate submitted also by the expert commissions responsible for training standards, that in recent years there has been a manifestation of stellar journalism, the promotion of investigative journalism (which are not occupation fundamentals). In the meantime, Polish media reserves much attention for themselves (mainly rivals), which makes them embarrassingly provincial.

In Wierzyński's article I have also found an important observation concerning the development of electronic public media, which run themselves with no political pressure and free from economic profit. As the journalists claim, there is the best "remedy for diseases spread by commercial media" ever. In Poland, as we know, there is a persistent campaign about their financial sources, and the way of administering local television and radio arouses much controversy too. It should be pointed out that the Citizens Public Media Committee, which was formed during the Polish Culture Congress in 2009 on the artists' idea, grew out of the contestation

12 Compare: M. Wierzyński, Czyja culpa, „Polityka” 2008, No. 24 (2658), pp.114-115. 
of "the appropriate" in the media by people associated mainly with "dough and power." 13

In the attempt to define the reasons for the unreal maintenance of the profession's standards, it is worth enumerating, among the causative factors, world processes such as media convergence, ownership concentration, point and transfer means' ownership globalization, plot unification, media interactivity, broadcast democracy (everyone can make a statement on the Internet); characteristic of the Polish media system - the fast expansion of the media after 1989, even with a limited press policy, uncritical acceptance of modernity determinants without even their value recognition e.g. provocations, journalistic investigations, replacing language journalism species with pictures and language, enabling communication channels to the recipient with different levels of responsibility consciousness for what they say, journalists' and the Republic of Poland associations, and treating the media like a political trophy. It is worth noticing that deregulation outcomes of the media systems in Europe were the same as in France, Italy and Greece. Thinking mainly about imitating commercial media by their public counterparts, with regard to content (entertainment superiority, series, formatted competitions) and the means of financing (minimizing costs, issuing commercials and hidden commercials). Electronic public media are getting closer to the commercial ones, especially as the operative journalism model assumes celebrity creation, ritualization and emotionality. Joining these three factors meant that - as stated by Henrik Ornebring - the media and journalists' activities plot "became idiotic." Journalists become celebrities, talk-show hosts, "in all specialisms" or public life eavesdroppers. ${ }^{14}$

13 Ibidem, p.115.

14 H. Ornebring, Televising the public sphere: Forty years of current affairs debate programmes on Swedish television, "European Journal of communication" 2003, No.18, pp. 501-527. See more: K. Williams, Media w Europie, Warszawa 2008; K. Jakubowicz, Media publiczne: początek końca czy nowy początek, Warszawa 2007; T. Mielczarek, Monopol, pluralizm, koncentracja. Środki komunikowania masowego w Polsce w latach 1986-2006, Warszawa 2007; T. Kowalski, Media i pieniądze. Ekonomiczne aspekty działalności środków komunikowania masowego, Warszawa 1998. 
One of the important aspects of the problem is, above all, an apparent worldwide drop in printed press reading, which eventually will cause title fusion and closure, work market destabilization and the increasing pressure towards text attractiveness.

At some point, putting media under the rules of the free market, excluding them from performing educational or culture-making tasks and missions, will reverse work value hierarchy. Are those tendencies permanent, or, as stated by Wierzyński, just typical of the early development of the democratic system? Much of it depends on journalists' training, and certain behaviour of those who are claimed to be the authority or model for apprentices. First of all, State policy has a great influence on the journalistic values. There is a vast array of expectations here, from the long law novelization through media facilities depolitization and entrusted administration with specialists in public media financing, regulation, and the support of local media. I also think that journalists, at this point, should be able to tell the difference between opportunism, and the less effective, but gradually establishing their position, reliable sport practicing. Then the time and economic markers pressure would not threaten the standards, and the new journalistic model, improved by the Internet, would be better, because of its adaptation to contemporary dynamics and requirements. 